\title{
Digital Entrepreneurship and Digital Entrepreneurship Approach in Turkey: Ankara Case
}

\author{
Abdullah Ballı a \\ adr1240201073@gmail.com
}

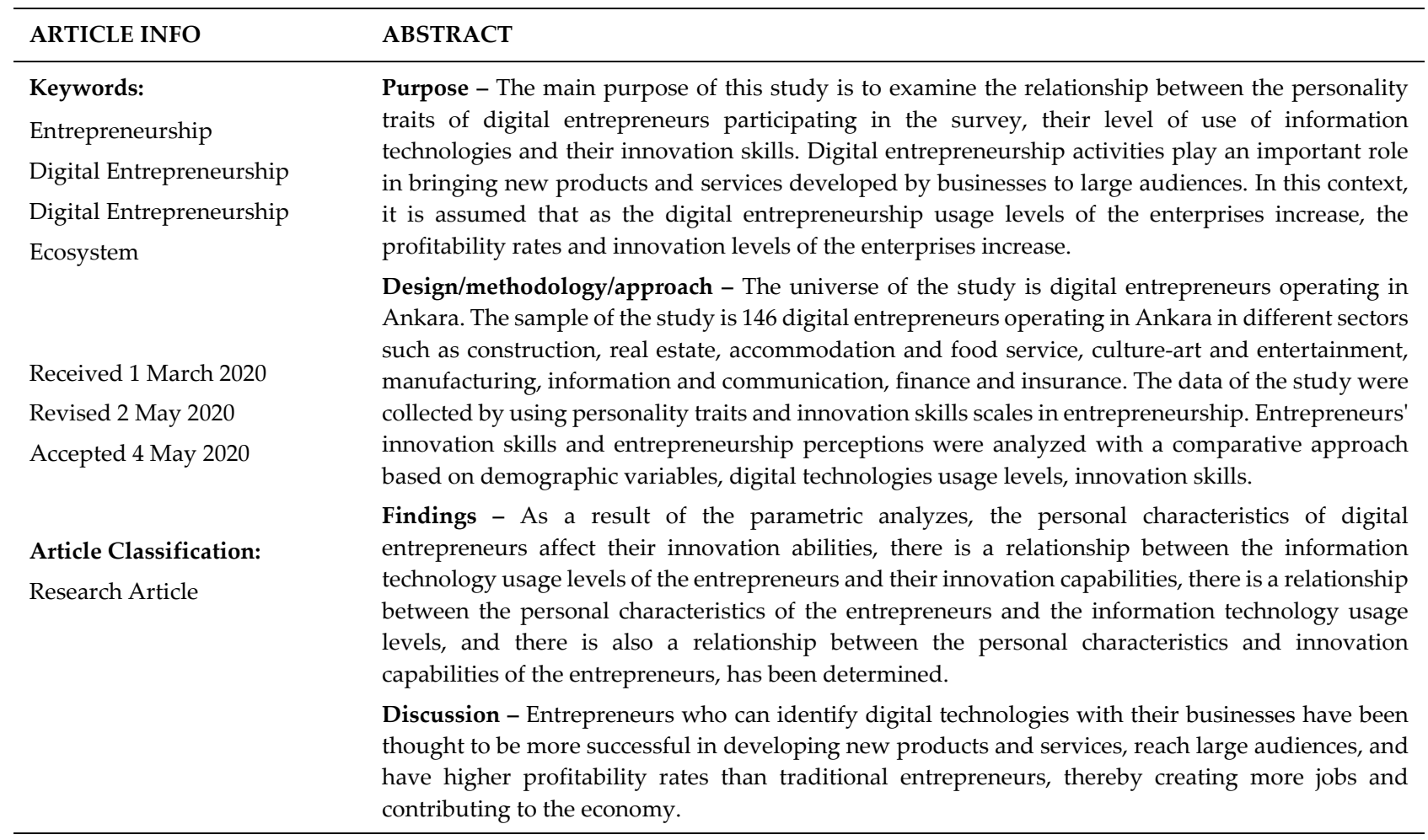

\section{INTRODUCTION}

Digital entrepreneurship; It is a type of entrepreneurship that is realized by creating innovative products and services that can be reached by many segments of the society and selling these emerging products and services on many different platforms by taking advantage of the developments that occur thanks to the advances in technology. With the global spread of the internet, developments in the field of digital entrepreneurship has gained momentum. Newly developed software and applications, social networks, easier access to the internet and developments in information technologies have offered many new opportunities for entrepreneurs. Thanks to these developments, digital entrepreneurship has emerged as a new form of entrepreneurship in entrepreneurship. Digital entrepreneurship can be defined as the realization of entrepreneurship on digital platforms. These activities have brought flexibility, speed, cost, quality, responding to different demands and needs, as well as innovations that create the phenomenon that there are some new demands and needs in the consumer. It can be said that digital entrepreneurship is one of the most sought-after entrepreneurship types due to its many convenience and cost advantages. Digital entrepreneurship also provides manufacturers with a job opportunity where they can easily sell their products and services in the digital markets.

Social networks, easy and cheap access to the internet, newly developed mobile software and applications and new generation information technologies have brought many new opportunities to entrepreneurs. Digital entrepreneurship, also referred to as electronic entrepreneurship, is an entrepreneurship activity carried out 
by developing, marketing and selling products and services that individuals can obtain through the internet. Many services such as mobile software, social networks and platforms, sites developed for information and entertainment, computer software, education and consultancy can be shown as examples of digital entrepreneurship types (Vural and Cavuş, 2017: 51). New entrepreneurship types that use internet-based information technologies are expressed as entrepreneurship or digital entrepreneurship in the digital field. Digital entrepreneurship, which enables businesses to find new opportunities, has a significant share in introducing innovative business practices (Jelonek, 2015: 1014).

Digital entrepreneurship is defined as digitalizing one or more of predefined business models in terms of products, distribution and workplace by the entrepreneur (Hair et al., 2012). According to Hull et al. (2007: 5), digital entrepreneurship is a sub-category of entrepreneurship that needs to be digitized physically in a traditional organization. In summary, digital entrepreneurship consists of selling digital products or services over electronic networks (Guthrie, 2014: 115).

In a conscious consumer society where the transfer of information and technology accelerates thanks to the developments in information and communication technologies, and where geographical distances do not constitute an obstacle, the system, which emerged thanks to the current developments and expressed as a new economic order, has been named digital entrepreneurship by adding different and new perspectives to the entrepreneurship understanding. This situation allows the entrepreneurs to obtain a competitive strategy that offers new opportunities and enables them to turn the difficulties that exist in an uncertain environment in their favor and turn this into a profitable investment.

The purpose of this study, give information about definition of digital entrepreneurship that offers many new opportunities for entrepreneurs, types, provide information about the characteristics and digital entrepreneurship ecosystem. In this study that carried out with 146 entrepreneurs, digital entrepreneurship approach in Turkey, explain to importance of digital entrepreneurship for Turkey and make suggestions for the development of this new type of entrepreneurship. In addition, when studies are examined, it is evaluated that the study will fill an important deficit due to the limited number of studies.

\section{LITERATURE REVIEW}

It is understood that there are few studies in the literature in terms of digital entrepreneurship. It is seen that some of the existing researches are case studies, some of them are qualitative studies within a certain sample and the rest are theoretical researches and studies. Hull et al. (2007) tried to express the differences between entrepreneurship typology and digital and traditional entrepreneurship in the typology studies of digital entrepreneurship. Davidson and Vaast (2010) have identified the existence of factors and relationships with social networks for digital entrepreneurship opportunities, entrepreneurs' success and motivation in relation to digital entrepreneurship. Hair et al. (2012), in their study entitled "Market orientation in digital entrepreneurship: Web 2.0 advantages and challenges in a networked world", explained that what opportunities and threats the digital age and its requirements include for entrepreneurs. Liao et al. (2013), in their study entitled "Six aspects of technology management: on a study in the digital business sector", that made important inferences about how the digital business industry can be managed as well as process and product innovations. Guthrie (2014) stated in his project "Entrepreneurship education: within the scope of launching a specialist block in e-commerce at European business school", that students showed great interest due to the low costs of digital entrepreneurship. Dutot and Van Horne (2015), in their study entitled "The intention of digital entrepreneurship in a developed and developing country" that they concluded that the factors of affecting entrepreneurial intent in their quantitative studies about examples of France and UAE. Castro et al. (2016) reached the conclusion that digital music, digital games (multiple regions) and social networks have the potential to develop new products in their study on the potential new business opportunities resulting from the combination of digital music and game industries with network-based innovation. Hu et al. (2016), in their study on the role of corporate entrepreneurship in the construction of the digital ecosystem, have revealed that corporate entrepreneurship has an important role in a developing digital entrepreneurship ecosystem. Giones and Brem (2017) have demonstrated the characteristics of digital entrepreneurship by characterizing digital technology entrepreneurship. Nambisan (2017) has explained that how entrepreneurs can deal with the uncertainties in the market thanks to digital approaches in his study on the meeting of digital entrepreneurs with digital technologies. Troxler and Wolf (2017), in their study entitled "Which activities do digital producer-entrepreneurs create their own business models", have stated that 
traditional entrepreneurship started to be replaced by digital entrepreneurship. Sussan and Acs (2017) have focused on the digital entrepreneurship ecosystem and its components in order to better express the concept of digital entrepreneurship. Srinivasan and Venkatraman (2018), in their study entitled "Entrepreneurship on digital platforms: a network view", have revealed that what are the success factors related to entrepreneurs and platforms.

\section{DIGITAL ENTREPRENEURSHIP AND DIGITAL ENTREPRENEURSHIP ECOSYSTEM}

Digital entrepreneurs are also defined as a sub-category of traditional entrepreneurs, which ensures that everything physically embodied in traditional organizations is done in a digital environment (Hull, 1980: 1118). Digital entrepreneurship is defined as the search for opportunities using digital media and other information and communication technologies (Efeoğlu, 2014: 103-118). Digital entrepreneurship is a concept that emerges from the developing and widespread information and communication technologies. Digital entrepreneurship is the attempt of the current entrepreneurship environment to adapt itself to the needs of the digital age in the face of developing and changing conditions (Le Dinh et al., 2018: 1). Digital entrepreneurship is defined as the search for opportunities using digital media and other information and communication technologies (Davidson and Vaast, 2010: 2). E-entrepreneurship, also called digital entrepreneurship, is also defined as tracking opportunities based on the use of digital media and other information and communication technologies (Dy et al., 2016: 287). According to Solak and Sarıdoğan (2011), digital entrepreneurship is defined as the process of transforming technological products produced in research and development centers into an economic value in technology-centered environments. According to Santana (2017: 18), digital entrepreneurship has included all new businesses and former companies that create economic and social value through digital technologies. According to Sussan and Acs (2017: 71), although digital entrepreneurship is an approach that predicts the use of information and communication technologies in new networks, systems and formats; according to Du et al. (2018: 2), digital entrepreneurship is the meeting of digital information and technologies with entrepreneurs.

The digital entrepreneur is the person who uses the internet to create commercial opportunities, to spread information, to collaborate with customers or partners (Millman et al., 2009: 245). Digital entrepreneurs are expressed as patient, determined, honest, resilient, experienced, imaginative, meticulous, attentive, researcher, people with business intelligence who can lead a team, know the customer and the market well, take risks and work in uncertain environments. Increasing internet usage leads to an increase in digital entrepreneurship activities (Ünsal, 2013).

In digital entrepreneurship, some or all of the traditional entrepreneurship activities take place digitally. In this context, there are three forms of digital entrepreneurship (Hull et al., 2007: 296):

Light digital entrepreneurship: Digital entrepreneurship is seen and implemented as a complementary element.

Medium digital entrepreneurship: Businesses digitally allocate more resources to products, distribution and some components in terms of creating added value.

Extreme digital entrepreneurship: It requires digital monitoring of all processes starting from the supply chain, from the production of the product to the end user.

Table 1. Differences Between Traditional and Digital Entrepreneurship

\begin{tabular}{|l|c|c|}
\hline & Traditional entrepreneurship & Digital entrepreneurship \\
\hline Enter the market & Difficult & Easy \\
\hline Production and storage & Difficult & Easy \\
\hline Distribution & Slower & Faster \\
\hline Workplace & Easier & Digital workplace \\
\hline Organizational commitment & Face to face & $\begin{array}{c}\text { With computer and digital } \\
\text { technologies }\end{array}$ \\
\hline Communication form & Hierarchical & Flexible and collaborative \\
\hline Organizational structure & &
\end{tabular}

Source: Hull et al., 2007: 296-298; Hafezieh et al., 2011: 269-270; Yaghoubi et al., 2012: 1048; Özdemir, 2016: 6. 
Components within the digital entrepreneurship ecosystem have a large share in shaping digital entrepreneurship. Therefore, emerging new business practices are the social and technical aspects of this ecosystem. These ecosystems are also known as online capital. In this way, digital entrepreneurship ecosystems encourage entrepreneurs to generate ideas, identify and allocate resources, take advantage of digital market opportunities, gather information and create legitimacy for innovations (Davidson and Vaast, 2010: 1-10). Smith et al. (2017) see the digital entrepreneurship ecosystem as an area of interaction in terms of achieving the desired outcomes of entrepreneurs.

The digital entrepreneurship ecosystem consists of stakeholders such as government, users (industrial enterprises), technology suppliers, educational institutions (universities, research institutes), investors (including financial institutions) and other companies in the businesses' value chain. One of the key elements that trigger transformation is the fulfillment of these stakeholders' roles in cooperation and coordination. One of the most important factors in the development of digital entrepreneurship is the creation of favorable conditions for the formation of the digital entrepreneurship ecosystem. In order to contribute to the emergence and development of the digital entrepreneurship ecosystem, it is important to establish a technological infrastructure, collaborate between institutions, provide financial and technical support, accelerate research and development, and make legal arrangements to encourage the emergence of innovative products and services.

Engel and del-Palacio (2015) have identified the following basic behaviors to support the development of high technology based entrepreneurship in the digital entrepreneurship ecosystem:

An increase in human capital, financial capital and knowledge as a result of the emergence of the appropriate ecosystem

Entrepreneurship process involving the search for brutal opportunities regardless of resource limitations

Increased business development speed

A strategic global perspective

Incentives and targets that lead to closeness for cooperation

It is the development of global entrepreneurship cooperation networks thanks to the rapid and easy transfer of information flow with the new generation technologies that are developing.

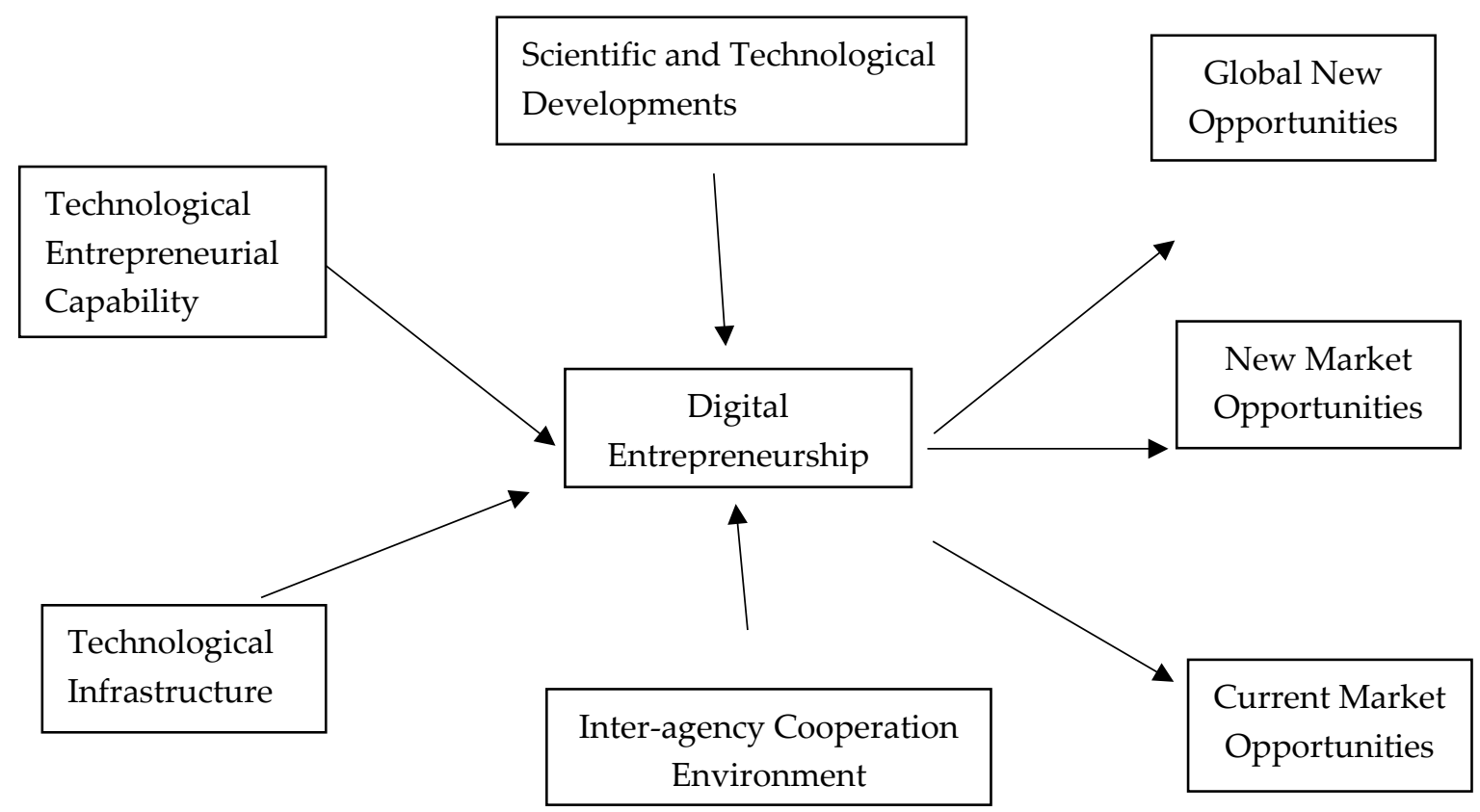

Figure 1. Inputs and Outputs of the Digital Entrepreneurship Ecosystem

Source: (Chaston, 2017: 18). 
Digital entrepreneurship has enabled the emergence of new opportunities and markets globally, and also encouraged the intensive use of the existing market by establishing a technological infrastructure and by using the scientific and technological developments, as a result of the cooperation between institutions.

\section{METHOD}

In the study; 161 digital entrepreneurs in Teknokent, Elektrokent, OSTIM and Organized Industrial Zones operating in Ankara were interviewed face-to-face and data were collected through a questionnaire. However, 15 digital entrepreneurs participating in the questionnaire were not included in the study because of their insufficient responses. The universe of the study is digital entrepreneurs operating in Ankara. The sample of the study is 146 digital entrepreneurs operating in Ankara in different sectors such as construction, real estate, accommodation and food service, culture-art and entertainment, manufacturing, information and communication, finance and insurance. The data of the study were collected by using personality characteristics and innovation skills scales in entrepreneurship. Entrepreneurs' innovation skills and entrepreneurship perceptions were analyzed with a comparative approach based on demographic variables, digital technologies usage levels, innovation skills.

\subsection{Research Hypotheses}

It is assumed that the personal characteristics of entrepreneurs affect the level of information technology usage and their ability to innovate. In this context, the following hypotheses were created to understand whether there is a relationship between the personal characteristics of entrepreneurs, innovation skills, information technology usage levels, the information technology usage levels of entrepreneurs and innovation skills, and whether the personal characteristics of entrepreneurs affect their innovation capabilities.

H1: There is a relationship between the personal characteristics of the entrepreneurs and their innovation skills.

H2: There is a relationship between the personal characteristics of entrepreneurs and the level of information technology usage.

H3: There is a relationship between the level of information technology usage of entrepreneurs and their innovation skills.

H4: The personal characteristics of entrepreneurs affect their innovation abilities.

\subsection{Data Collection Method and Measuring Tools}

Marvel and Lumpkin (2006) and (2007) studies were used in the research scales. The questionnaire developed for collecting the data needed was completed in 2018 by the entrepreneurs / managers who were managers in their own businesses for two months. In the study, firstly, it was tried to establish a direct relationship with the entrepreneur, who is also the owner of the business, and was informed about the nature, purpose and method of collecting information. In order to carry out the screening with healthier data, the questionnaires were filled with face to face interview technique. SPSS 25 package program was used in the analysis of the data collected in the research. In order to summarize the raw data and get a general idea about the distribution, Cronbach Alpha analysis was used because the frequency is an arithmetic mean in terms of expressing the average of the sample taken from the main mass and the reliability of the questionnaire form. Considering the complex relationship of the collected information with other information in the data, statistical techniques have been used to a great extent to facilitate the analysis and interpretation of the sufficient number of data collected.

\subsection{Data Collection Means and Reliability of Scales}

A questionnaire form consisting of 4 parts was used. In the first part of the data collection tool, information about entrepreneurship, in the second part, information about the information technology infrastructure of the entrepreneurs, in the third part, the questions that measure the personal characteristics of the entrepreneurs and in the last part the innovation capabilities of the entrepreneurs were asked. In the research, a questionnaire was created by using the Marvel and Lumpkin (2006) and (2007) studies. The questions addressed to the entrepreneurs were created as "strongly disagree" (coded as 1) and "strongly agree" (coded as 5) with a 5-point Likert scale). 
Table 2. Content of Survey Form

\begin{tabular}{llr}
\hline Section & \multicolumn{1}{c}{ Content of the Sections Questions } & \multicolumn{1}{c}{$\begin{array}{c}\text { Rank of } \\
\text { Questions }\end{array}$} \\
\hline $\mathbf{1 .}$ & $\begin{array}{l}\text { Questions about Entrepreneurs, } \\
\text { Business and Entrepreneurship } \\
\text { Questions about Information } \\
\text { Technologies } \\
\text { 2. }\end{array}$ & $1-21$ \\
$\mathbf{3 .}$ & $\begin{array}{l}\text { Questions About the Entrepreneur's } \\
\text { Questions to Determine the } \\
\text { Innovation Capabilities of } \\
\text { Entrepreneurs }\end{array}$ & $34-54$ \\
\hline Total & & $55-64$ \\
\hline
\end{tabular}

The concept of reliability means that the measured properties are measured correctly. The high degree of reliability assumes the prerequisite for the validity of a study. Cronbach Alpha coefficient is one of the most widely used methods to test reliability. The low value of the Cronbach Alpha coefficient (close to zero) indicates that the variables are not intrinsically related. For the newly developed scales, the acceptable Cronbach Alpha coefficient is between 0.50 and 0.60, while the Cronbach Alpha coefficient greater than 0.70 indicates that the internal consistency is high (Büyüköztürk, 2007: 45). In this study, Cronbach Alpha coefficient was used to evaluate the reliability of the scales in the questionnaire.

Table 3. Reliability Coefficients of Scales

\begin{tabular}{|c|c|c|c|c|}
\hline Scale & Measuring Range & Number of İtems & Cronbach Alpha & Sample Size \\
\hline $\begin{array}{l}\text { Personality } \\
\text { Characteristics in } \\
\text { Entrepreneurship (When } \\
\text { the idea of starting a } \\
\text { business arises) }\end{array}$ & 5-point Likert scale & 20 & 918 & 146 \\
\hline $\begin{array}{l}\text { Personality } \\
\text { Characteristics in } \\
\text { Entrepreneurship (When } \\
\text { the business is } \\
\text { established) }\end{array}$ & 5-point Likert scal & 20 & ,931 & 146 \\
\hline $\begin{array}{l}\text { Innovation Capabilities of } \\
\text { Entrepreneurs }\end{array}$ & 5-point Likert scale & 10 & ,856 & 146 \\
\hline
\end{tabular}

As can be seen from the table, it is understood that the reliability of the scales used in the research is between ,856 and ,931 and our scales are reliable.

\section{FINDINGS}

In this section, the socio-demographic characteristics of the entrepreneurs, the personality characteristics of the entrepreneurs and the level of using information technologies, the relationship between the personality characteristics and the innovation skills, the relationship between the technology usage levels and the innovation skills had been tried to be measured.

\subsection{Socio-Demographic Characteristics of Entrepreneurs}

Table 3. examines the socio-demographic characteristics of the entrepreneurs included in the research. In this context, the entrepreneurs' age ranges, gender, educational status, provinces in which they are registered to 
A. Ballı 12/2 (2020) 1058-1071

the population, father's professions, , their level of achieving their goals and whether they receive consultancy services and they know a foreign language were questioned.

Table 4. Socio-Demographic Characteristics of Entrepreneurs

\begin{tabular}{|c|c|c|}
\hline Demographic Characteristics & Number & $\%$ \\
\hline $\begin{array}{l}\text { Age Range } \\
18-25 \text { Age }\end{array}$ & -- & -- \\
\hline 26-30 Age & 18 & 12.3 \\
\hline 31-35 Age & 39 & 26.7 \\
\hline 36-40 Age & 58 & 39.7 \\
\hline 41-45 Age & 31 & 21.3 \\
\hline 45 Age and Over & -- & -- \\
\hline \multicolumn{3}{|l|}{ Gender } \\
\hline Female & 14 & 9.6 \\
\hline Male & 132 & 90.4 \\
\hline \multicolumn{3}{|l|}{ Marital Status } \\
\hline Married & 127 & 87 \\
\hline Single & 19 & 13 \\
\hline \multicolumn{3}{|l|}{ Education Status } \\
\hline Primary Education & -- & -- \\
\hline High School & 9 & 6.1 \\
\hline University & 113 & 77.4 \\
\hline Master and Ph.D. & 24 & 16.5 \\
\hline \multicolumn{3}{|l|}{ Registered province } \\
\hline Ankara & 32 & 21.9 \\
\hline Other & 114 & 78.1 \\
\hline \multicolumn{3}{|l|}{ Father's occupation } \\
\hline $\begin{array}{l}\text { Entrepreneur / businessman / } \\
\text { Craftsman/Tradesman }\end{array}$ & 94 & 64.4 \\
\hline Worker / Officer / Retirement & 23 & 15.7 \\
\hline Farmer & 19 & 13 \\
\hline Other & 10 & 6.9 \\
\hline \multicolumn{3}{|l|}{ Well-Known Foreign Language } \\
\hline English & 56 & 38.3 \\
\hline German & 21 & 14.4 \\
\hline Other & 9 & 6.2 \\
\hline Unknowing & 60 & 41.1 \\
\hline \multicolumn{3}{|l|}{ Level of Achievement } \\
\hline Very Low & -- & -- \\
\hline Low & 14 & 9.6 \\
\hline Middle & 71 & 48.6 \\
\hline High & 50 & 34.2 \\
\hline Very High & 11 & 7.6 \\
\hline \multicolumn{3}{|l|}{ Consultancy service } \\
\hline Yes & 18 & 12.3 \\
\hline No & 128 & 87.7 \\
\hline
\end{tabular}

As seen in Table 4, it is understood that $87 \%$ of the entrepreneurs participating in the research are between the ages of 31 and 45. This situation tells us that digital entrepreneurship is especially accepted among middle- 
aged individuals. It is understood that the rate of women entrepreneurs among the entrepreneurs participating in the research is low by $9 \%$. This situation shows the presence of a more dominant male entrepreneur. The fact that entrepreneurs are mostly married shows that the traditional family structure continues. It is understood that approximately $94 \%$ of the entrepreneurs participating in the research have university and postgraduate education. This shows that the high level of education of individuals has increased the interest in digital entrepreneurship. It shows that approximately $80 \%$ of entrepreneurs continue their entrepreneurship activities in Ankara, although they are registered in the population of other provinces. This situation shows that entrepreneurs prefer here because Ankara is a capital and a big city and it is more convenient to find financial resources. It is seen that the entrepreneurship tendencies of the individuals whose father profession is entrepreneur, tradesman or businessman are quite high. It shows that individuals whose father's profession is an entrepreneur or tradesman are more willing about digital entrepreneurship. In addition, it is understood that most of the entrepreneurs know at least one foreign language at a good level and their success rate is medium and above average. This means that digital entrepreneurs are able to communicate with the outside world at a high level, thus achieving their goals. It is seen that approximately $87 \%$ of the entrepreneurs did not receive any consultancy services. This situation causes the success data of entrepreneurs to remain at medium level. With a good and accurate guidance, this level of success can be increased to very high levels.

\subsection{Characteristics of Businesses Participating in the Research}

In this section, the characteristics of enterprises such as export status, number of employees, in which area and how long they operate, whether they have a patented brand / product, and management styles will be examined.

Table 5. Characteristics of Businesses

\begin{tabular}{lcc}
\hline Business Characteristics & Number & $\%$ \\
\hline Business Administration & 79 & 54.1 \\
Entrepreneur & 24 & 16.4 \\
Family members & 37 & 25.3 \\
Partners & 6 & 4.2 \\
Professional manager & & \\
Business segment & 17 & 11.6 \\
Construction & 6 & 4.1 \\
Real estate & 31 & 21.2 \\
Accommodation and food service & 10 & 6.9 \\
Culture-art and & & \\
Entertainment & 49 & 33.6 \\
Manufacturing & 26 & 17.8 \\
Information and communication & 7 & 4.8 \\
Finance and insurance & & \\
Activity period & 19 & 13 \\
Less than 2 years & 51 & 34.9 \\
2-5 years & 76 & 52.1 \\
5-10 years & -- & -- \\
10 years and over & & \\
Number of employees & -- & -- \\
Less than 9 & 33 & 22.6 \\
From 10 to 49 & 99 & -- \\
Between 50-99 & 14 & \\
Between 100-150 & -- & \\
Over 150 & &
\end{tabular}




\section{Registered trademark or patent}

Yes

No

\section{Export status}

No exports

Direct export

Indirect exports

Both of them

As seen in Table 5, 70\% of businesses are managed by entrepreneurs or family members. This situation shows that entrepreneurs are in the tradesman/craftsman entrepreneur mentality. It is understood that the most intensive activities in terms of digital entrepreneurship are carried out by entrepreneurs operating in the field of manufacturing. This shows that entrepreneurs benefit from digital entrepreneurship activities more than other sectors in order to deliver their products to a wider consumer base. It is understood that $87 \%$ of the entrepreneurs operate between 2 and 10 years. This indicates that digital entrepreneurship' history is a short in terms of Turkey. When the number of personnel of the enterprises is analyzed, it is seen that the majority of the enterprises are composed of SMEs. In this way, it is once more seen that SMEs have an important place in terms of both traditional and digital entrepreneurship in Turkey. From Table 5, it is understood that $60 \%$ of the enterprises do not have their own patents or trademarks. This shows that digital entrepreneurs do not have enough information on certain topics and should receive consultancy services. Also, it is seen that $64 \%$ of the entrepreneurs do not export. Although digital entrepreneurship' main target is to reach a wider consumer, exports in terms of digital entrepreneurs in Turkey are understood to be low and insufficient.

\subsection{The Relationship Between Entrepreneurs' Personal Characteristics and Novelty in Innovation}

The average values of the factors of the personal characteristics and innovation skills of the entrepreneurs are given in Table 6.

Table 6. The Relationship Between Personal Characteristics and Invention

\begin{tabular}{lccc}
\hline Personal Characteristics- Invention & Mean & Standard Deviation & N \\
\hline $\begin{array}{l}\text { Personal Characteristic: Product and } \\
\begin{array}{l}\text { Market } \\
\text { Personal Characteristic: Product and }\end{array}\end{array}$ & 4,4711 &, 53025 & 146 \\
$\begin{array}{l}\text { Customer } \\
\text { Personal Characteristic: Technological }\end{array}$ & 4,4113 &, 51234 & 146 \\
$\begin{array}{l}\text { Knowledge } \\
\text { Production Innovation }\end{array}$ & 4,2874 &, 71545 & 146 \\
Process and Marketing Innovation & 3,9215 &, 66319 & 146 \\
\hline
\end{tabular}

It is understood that the scale applied for the personal characteristics of entrepreneurs consists of 3 factors and these factors constitute $71,796 \%$ of the total variance, respectively $28.419 \%, 23.633 \%$ and $19.744 \%$. It is understood that the scale applied to measure the innovation skills of entrepreneurs consists of 2 factors and constitutes $57,898 \%$ of the total variance, $29,036 \%$ and $28,862 \%$ respectively. In Table 7 , an evaluation is made regarding the relationship of these factor loads. 
Table 7. Correlation Between Personal Characteristics and Innovation Capabilities

\begin{tabular}{|c|c|c|c|c|c|}
\hline $\begin{array}{l}\text { Personal Characteristics and Innovation } \\
\text { Ability }\end{array}$ & 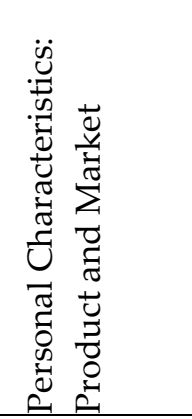 & 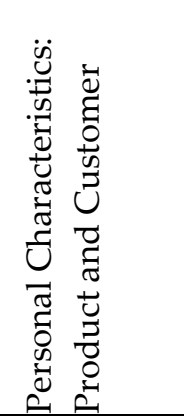 & 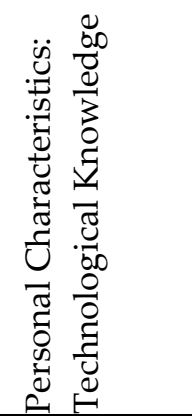 & 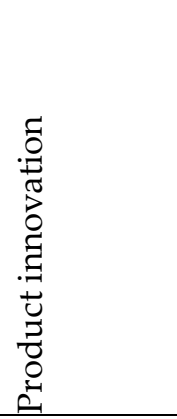 & 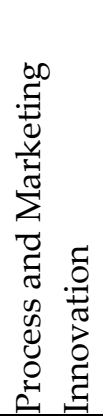 \\
\hline \multicolumn{6}{|l|}{ Personal Characteristics: Product and } \\
\hline Market & 1 & & & & \\
\hline \multicolumn{6}{|l|}{ Personal Characteristics: Product and } \\
\hline Customer & $688^{* *}, 000$ & 1 & & & \\
\hline $\begin{array}{l}\text { Personal Characteristics: Technological } \\
\text { Knowledge }\end{array}$ & ,736**,000 & $, 544^{* *}, 000$ & 1 & & \\
\hline Product Innovation & $, 494^{* *}, 000$ & $365^{*}, 001$ & $, 596^{* *}, 000$ & 1 & \\
\hline Process and Marketing Innovation & $, 305^{*}, 005$ & ,379*, 001 & $, 431^{* *}, 000$ & $, 392^{* *}, 000$ & 1 \\
\hline
\end{tabular}

Note: (i): n:146

According to the Spearman correlation test, it is seen that there is a high level of positive and significant relationship between factors involving personal characteristics and factors related to innovation abilities. In this context, it is understood that entrepreneurs have a positive and strong relationship between their personal knowledge and innovation capabilities in areas such as product, market, customer and technology. As a result, it can be concluded that the innovation that entrepreneurs make in a field is supported by their personal characteristics. According to this result, H1: "There is a relationship between the personal characteristics of the entrepreneurs and their innovation skills" is accepted.

Another correlation is the relationship between entrepreneurs' personality characteristics and information technology and innovation variables. This situation is explained in Table 8.

Table 8. The Relationship Between Personal Characteristics and Information Technologies and Innovation

\begin{tabular}{|c|c|c|c|c|c|c|}
\hline $\begin{array}{l}\text { Personal Characteristics and } \\
\text { Innovation Ability }\end{array}$ & 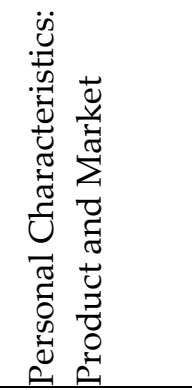 & 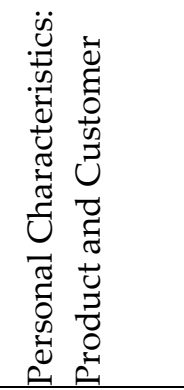 & 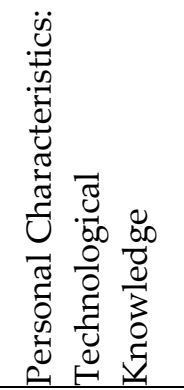 & 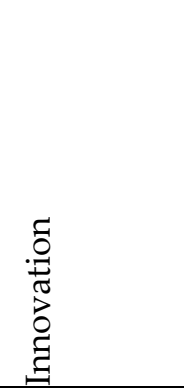 & 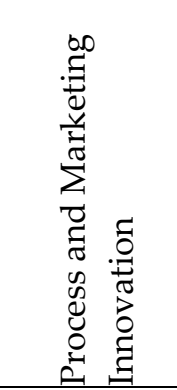 & 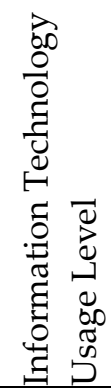 \\
\hline \multicolumn{7}{|l|}{ Personal Characteristics: } \\
\hline $\begin{array}{l}\text { Product and Market } \\
\text { Personal Characteristics: }\end{array}$ & 1 & & & & & \\
\hline Product and Customer & $688^{* *}, 000$ & 1 & & & & \\
\hline $\begin{array}{l}\text { Personal Characteristics: } \\
\text { Technological Knowledge }\end{array}$ & $, 736^{* *}, 000$ & $, 544^{* *}, 000$ & 1 & & & \\
\hline Product Innovation & $, 494^{* *}, 000$ & ,365*, 001 & $, 596^{* *}, 000$ & 1 & & \\
\hline $\begin{array}{l}\text { Process and Marketing } \\
\text { Innovation }\end{array}$ & $, 305^{*}, 005$ & 379*, 001 & $, 431^{* *}, 000$ & ,392**, 000 & 1 & \\
\hline $\begin{array}{l}\text { Information Technology Usage } \\
\text { Level }\end{array}$ & $, 499^{* *}, 000$ & $, 387^{* *}, 000$ & $, 411^{* *}, 000$ & ,696 $6^{* *}, 000$ & $318^{*}, 005$ & 1 \\
\hline
\end{tabular}

Note: (i): n:146 
The correlation test conducted to examine the relationship between the level of information technology usage, innovation capabilities and human capital characteristics is shown in Table 8. According to the Spearman correlation test, it is seen that there is a high level of positive and significant relationship between the level of use of information technologies and factors including personal characteristics and innovation abilities. In this context, it can be concluded that there is a relationship between entrepreneurs' information technology usage levels and their innovation skills and personal characteristics. In particular, it was observed that there was a high $(, 696)$ relationship between the level of use of information technologies and innovation factors. In this context, H2: " There is a relationship between the personal characteristics of entrepreneurs and the level of information technology usage " and H3: " There is a relationship between the level of information technology usage of entrepreneurs and their innovation skills " hypothesis are accepted.

Anova test regarding the last hypothesis of the research is given below. As can be seen in Table 9, it is understood that the personal characteristics of entrepreneurs affect their innovation abilities.

Table 9. Relationship Between Personal Characteristic and Innovation Ability Anova Test Results

\begin{tabular}{lccccc}
\hline Source of Variance & Sum of Squares & df & Mean Square & F & Sig. \\
\hline Between Groups & 14,877 & 2 & 7,438 & 25,385 &, 000 \\
Within Groups & 39,052 & 133 &, 293 & & \\
Total & 53,929 & 135 & & & \\
\hline
\end{tabular}

Note: (i):f=25,385; (ii) $\mathrm{p}<0,05$

There is a significant difference between the level of use of the information systems of the entrepreneurs participating in the survey and their innovation skills. In this context, H:4 "The personal characteristics of entrepreneurs affect their innovation abilities" hypothesis is accepted.

\section{DISCUSSION AND CONCLUSION}

According to the World Economic Forum (WEF), the value that digital transformation will create socially and economically is expected to total \$ 100 trillion over a period of 10 years. The total net economic benefit of digitalization is estimated to be approximately $\$ 30$ trillion, along with other sectors (WEF, 2016). Thanks to digital entrepreneurship and digital transformation in the next decade, it may be possible to have a big share in such an important market. Therefore, it is necessary to make legal arrangements for the emergence and development of the appropriate digital entrepreneurship ecosystem.

It is understood that digital entrepreneurship will become widespread in many areas globally in the coming period. For this reason, the enterprises should evaluate the advances in digital technologies as opportunities and develop new forms of organization by using technologies that are compatible with their own business structures and future goals, and be able to meet the ever-changing demands and needs. In addition to a number of incentives and supports from legislative, it is important to implement practices and arrangements that will increase entrepreneurs' awareness of the importance and requirements of digital transformation. In addition, activities that will develop industry-university-entrepreneur-oriented collaborations on digital entrepreneurship should be put into practice. Centers that provide consultancy services and applied entrepreneurship training to entrepreneurs on issues they need or will need about digital entrepreneurship and digital transformation should be established.

Starting from primary school, trainings with application weight for the development of digital skills in all levels of basic, vocational and higher education and business life are required to train the qualified workforce needed and to improve the competencies of the existing workforce. Creating a technology infrastructure with strong competencies in digital technology research and developed global and national collaborations should be among the primary targets. In order to achieve digital transformation, our country must have a strong communication infrastructure. This infrastructure; in addition to making physical investments, it also requires the development of data communication standards and data security. In terms of the sustainability of the digital transformation process, the quality and quantity of the companies that develop digital technology products and services should be increased. On the other hand, in order for the digital transformation process 
to work correctly and effectively, the knowledge and awareness level of the companies about digital technologies and potential contributions to be provided with these technologies should be increased. With the increase of awareness levels of businesses, digital transformation processes can be realized with a certain strategy and an appropriate budget allocated under this strategy. It is necessary to increase the awareness levels of the enterprises, to introduce examples of good practices and to spread these practices, and to develop collaborations among stakeholders. In this context, the things to be done by the Ministry of Science, Industry and Technology and TUBITAK are given below.

Ministry of Science, Industry and Technology;

It should cooperate with market actors by implementing incentives to develop digital entrepreneurship models in line with country dynamics,

Reviewing and developing the necessary incentives and support mechanisms for production infrastructures that will enable critical and leading technologies to be produced by domestic businesses, including pilot production and demonstration supports.

\section{If TÜBITTAK;}

To take measures to implement programs that encourage innovation in important areas such as artificial intelligence, smart sensor, disconnected robot technologies, internet of things, big data, cyber security, and cloud computing,

To meet the legislative needs that will emerge with digitalization. In this context, to make necessary arrangements on issues such as facilitating electronic transactions (for example, inter-machine contracts, electronic payments etc.), protection of personal information and intellectual property rights, and ensuring that the ecosystem operates in a favorable regulatory framework,

To ensure the development of standards in areas such as data communication by making projects and physical investments that will facilitate digital transformation.

\section{REFERENCES}

Büyüköztürk, Ş. (2007). Sosyal Bilimler için Veri Analizi El Kitabı [Data Analysis Handbook for Social Sciences], Pegema Publishing] p. 45.

Castro S., F., Santos, M. and Alves, J. (2016). "Network-based innovation: the case for mobile gaming and digital music", European Business Review, Vol. 28 No. 2, pp. 155-175.

Chaston, I., (2017). Technological Entrepreneurship, Springer Nature, p.18.

Davidson,E. and Vaast, E. (2010). "Digital entrepreneurship and its sociometrical enactment", Proceedings of the 43rd Hawaii International Conference on System Sciences, pp. 1-10.

David, Hull. (1980). Renewing the Heffalump: Identifying Potential Entrepreneurs by Personality Characteristics, Journal of Small Business, New York, p.11-18.

Du, W.D.; Shan L.P.; Ning Z. and Taohua O. (2018). "From a Marketplace of Electronics to a Digital Entrepreneurial Ecosystem (DEE): The Emergence of a Meta-Organization in Zhongguancun, China", Info Systems J.; pp. 1-18.

Dutot, V. and Van Horne, C. (2015). “Digital entrepreneurship intention developed vs emerging country: an exploratory study France and the UAE", Transnational Corporations Review, Vol. 7 No. 1, pp. 79-96.

Dy, A. M., Marlow, S. and Martin, L. (2016). A Web of Opportunity or The Same Old Story? Women Digital Entrepreneurs Intersectional Theory. Human Relations, 70 (3), pp. 286-311.

Engel, J. S., and del-Palacio, I. (2015). Global clusters of innovation: Lessons from Silicon Valley. California Management Review, 57(2), pp. 37-58. 
Efeoğlu, E. (2014). "Çevreci Açıdan Girişim; Eko Girişimcilik" [Environmentalist Initiative; Eco Entrepreneurship], Çukurova Univ. Journal of Social Sciences Institute, Volume 23, Number 1, 2014, Adana, pp. 103-118.

Giones, F. and Brem, A. (2017). "Digital technology entrepreneurship: a definition and research agenda", Technology Innovation Management Review, Vol. 7 No. 5, pp. 44-51.

Guthrie, C. (2014). "The digital factory: a hands-on learning project digital entrepreneurship", Journal of Entrepreneurship Education, Vol. 17 No. 1, pp. 115-133.

Hair, N., Wetsch, L., Hull, C., Perotti, V. and Hung, Y.-T. (2012). “Market orientation digital entrepreneurship: advantages and challenges web 2.0 networked world", International Journal of Innovation and Technology Management, Vol. 9 No. 6, pp. 1-17.

Hafezieh, N.; Peyman A. and Farjam E., (2011). "Exploration of Process and Competitive Factors of Entrepreneurship in Digital Space: A Multiple Case Study in Iran", Education, Business and Society: Contemporary Middle Eastern Issues, Vol 4, No 4; pp. 267-279.

Hu, H., Huang, T., Zeng, Q. and Zhang, S. (2016). “The role of institutional entrepreneurship in building digital ecosystem: a case study of Red Collar Group (RCG)", International Journal of Information Management, Vol. 36 No. 3, pp. 496-499, doi: 10.1016/j.ijinfomgt.

Hull, C.E., Hung, Y.-T.C., Hair, N., Perotti, V. and DeMartino, R. (2007). “Taking advantage of digital opportunities: a typology of digital entrepreneurship", International Journal of Networking and Virtual Organizations, Vol. 4 No. 3, pp. 290-303.

Jelonek, D. (2015). The Role of Open Innovations in the Development of e-Entrepreneurship. International Conference on Communication, Management and Information Technology, pp. 1013-1022.

Le Dinh,T., Vu, M.C. and Ayayi, A. (2018). “Towards a living lab for promoting the digital entrepreneurship process", International Journal of Entrepreneurship, Vol. 22 No. 1, pp. 1-17.

Liao, A., Hull, C.E. and Sriramachandramurthy, R. (2013). "The six facets model of technology management: a study the digital business industry", International Journal of Innovation and Technology Management, Vol. 10 No. 4, pp. 1350019-1-1350019-24.

Marvel, Matthew R. and Lumpkin, G.T. (2006). "Opportunity recognition and innovation: how technology entrepreneurs use prior knowledge to construct radical innovations (interactive paper)," Frontiers of Entrepreneurship Research: Vol. 26 : Iss. 9 , Article 13.

Marvel, M.R. and Lumpkin, G.T. (2007). Technology entrepreneurs' human capital and its effects on innovation radicalness. Entrepreneurship Theory and Practice Baylor University, Waco, Texas 31(6), pp. 807-828.

Millman, C., Wong, W.-c., Li, Z., Matlay, H. (2009). Educating students for e-entrepreneurship in the UK, the USA and China. Industry and Higher Education, 23(3), pp. 243-252.

Nambisan, S. (2017). "Digital entrepreneurship: toward a digital technology perspective of entrepreneurship", Entrepreneurship Theory and Practice, Vol. 41 No. 6, pp. 1029-1055.

Özdemir, K. (2016). “Gerçek Mobil Kullanıcı Çağı” [Real Mobile User Age]. The Deloitte Times, April-May; pp. 5-10.

Santana, M. (2017). Digital Entrepreneurship: Expanding The Economic Frontier In The Mediterranean, European Institute of the Mediterranean (IEMED), http://www.iemed.org/publicacions-en/historicde-publicacions/papersiemed/20.-digital-entrepreneurship-expanding-the-economic-frontier-in-themediterranean, (Date of access: 13.10.2019).

Solak, F. ve Sarıdoğan, E. (2011). Sürdürülebilir İktisadi Büyüme ve Küresel Rekabet Gücü Bağlamında TeknoGirişimciliğin Rolü ve Önemi. Bilgi Toplumu, Bilişim Teknolojisi ve Girişimcilik içinde [The Role and Importance of Techno-Entrepreneurship in the Context of Sustainable Economic Growth and Global Competitiveness. In Information Society, Information Technology and Entrepreneurship], 21 (C. 150, 
A. Ballı 12/2 (2020) 1058-1071

pp. 274-283). 3rd International Congress on Entrepreneurship, presented Report, Bishkek: Kyrgyzstan-Turkey Manas University.

Smith, C., Smith, J.B. and Shaw, E. (2017). "Embracing digital networks: entrepreneurs' social capital online", Journal of Business Venturing, Vol. 32 No. 1, pp. 18-34.

Srinivasan, A. and Venkatraman, N. (2018). "Entrepreneurship digital platforms: a network centric view", Strategic Entrepreneurship Journal, Vol. 12 No. 3, pp. 54-71.

Sussan, F. and Zoltan J. ACS. (2017). “The Digital Entrepreneurial Ecosystem”, Small Business Economics, Vol 49; pp. 55-73.

Troxler, P. and Wolf, P. (2017). "Digital maker-entrepreneurs open design: what activities make up their business model?", Business Horizons, Vol. 60 No. 6, pp. 807-817.

Ünsal, S. (2013). Dijital Girişimcilik Rehberi Girişim Ekosistemi ile İlgili Temel Soruların Cevapları [Digital Entrepreneurship Guide Answers to Basic Questions About the Enterprise Istanbul: Interbank Card Center (BKM). https://bkm.com.tr/wp-content/uploads/2015/08/digital-girisimcilikrehberi.pdf (Date of access: 22.09.2019).

Vural, M. and Çavuş, Ş. (2017). Elektronik Girişimcilik ve Kırgızistan'da Uygulama Olanakları [Electronic Entrepreneurship and Application Opportunities in Kyrgyzstan]. Academic View Magazine. (69), pp. 50-64.

Yaghoubi, N. M.; Mahdi S.; Amir E. and Ebrahim S. (2012). “Identification of the Effective Structural Factors on Creating and Developing Digital Entrepreneurship in the Agricultural Sector", African Journal of Agricultural Research, Vol 7, No 6; pp. 1047-1053.

World Economic Forum, (2016). "The Future of Jobs: Employment, Skills and Workforce Strategy for the Fourth Industrial Revolution.", World Economic Forum, Cologny, Switzerland. 